\title{
Article
}

\section{Positive obligations and Article 4 of the European Convention on Human Rights: a defence of the UK's Human Rights Act 1998}

Turner, Ian David

Available at http://clok.uclan.ac.uk/11086/

Turner, Ian David ORCID: 0000-0002-8012-1480 (2014) Positive obligations and Article 4 of the European Convention on Human Rights: a defence of the UK's Human Rights Act 1998. The International Journal of Human Rights, 18 (1). pp. 94-114.

It is advisable to refer to the publisher's version if you intend to cite from the work. http://dx.doi.org/10.1080/13642987.2013.873408

For more information about UCLan's research in this area go to http://www.uclan.ac.uk/researchgroups/ and search for <name of research Group>.

For information about Research generally at UCLan please go to http://www.uclan.ac.uk/research/

All outputs in CLoK are protected by Intellectual Property Rights law, including Copyright law. Copyright, IPR and Moral Rights for the works on this site are retained by the individual authors and/or other copyright owners. Terms and conditions for use of this material are defined in the policies page. 


\title{
Positive obligations and Article 4
}

\author{
of the European Convention on
}

Human Rights: a defence of the

\section{UK's Human Rights Act 1998.}

\section{Ian Turner*}

Ian Turner

Senior Lecturer in Law

The Lancashire Law School

The University of Central Lancashire

Preston PR1 2HE

Email: idturner@uclan.ac.uk

Tel: 44 (0) 1772893074 


\begin{abstract}
The Human Rights Act 1998 came into effect in the UK in 2000, incorporating specific Articles of the European Convention on Human Rights, such as the freedoms from torture (Article 3) and slavery (Article 4), into British law. But this legislation, and the rights it enshrines, are under severe attack from Politicians and sections of the British Press. This article presents a strong defence of the statute, by reference to one of its notable achievements: the obligation it imposed on the UK to outlaw the holding of a person in slavery or servitude, or compelling them to perform compulsory labour.
\end{abstract}

\title{
Keywords
}

Human rights, the European Convention on Human Rights, the Human Rights Act 1998, freedom from slavery, human trafficking

\section{Introduction}

The United Kingdom (UK) does not possess a written Constitution, that is, it does not have either a single document or collection of documents labelled 'Constitution'. Assuming the UK does in fact have a Constitution, ${ }^{1}$ this is often said to be 'unwritten'. A typical feature of a written Constitution such as that possessed by the United States of America (USA) is the inclusion of a Bill of Rights. The USA's first ten amendments to its Constitution are collectively referred to as the Bill of Rights. The UK's Bill of Rights is the Human Rights Act 1998 (HRA) (thus the UK has sources of a Constitution if not a single written document with the title 
'Constitution'). It is now thirteen years since the HRA came into domestic effect in October 2000, enshrining specific Articles of the European Convention on Human Rights (ECHR) into British law.

The ECHR, which was first signed in Rome in 1950, was ratified by the UK in 1951. It was created by the Council of Europe, which was then a group of only ten European nations, with a view to promoting international action and collaboration to protect human rights. Currently there are 47 Member States of the Council of Europe, with a combined population exceeding 800 million, so the reach of the ECHR is significant. A discussion here of the ECHR rights in British law will, therefore, appeal to a much wider human rights audience than a UK one, especially since s.2 of the HRA obliges the British courts to have regard to the judgments of the European Court of Human Rights (ECtHR) in Strasbourg, France, in deciding violations of the ECHR in domestic law.

The ECHR rights incorporated into British law by virtue of the HRA include civil rights such as Article 2, the right to life, Article 3, the freedom from torture and inhuman and degrading treatment and punishment and Article 4, the freedom from slavery and servitude; and political rights such as Article 10, the freedom of expression, and Article 11, the freedom of association and assembly. But domestically the HRA and/or the ECHR have come in for much criticism, perhaps because the HRA's method in enforcing rights in British Law and/or the rights guaranteed by the ECHR are insufficiently protective of state interests? That is, the 'interpretive obligation' imposed on the courts by s.3(1) of the HRA to interpret all legislation in line with ECHR rights is perhaps too exacting, although it is prefaced by the phrase 
'so far at is possible to do so'? Similarly, the discretion conferred on the courts by s.4(2) of the HRA to declare legislation incompatible with the ECHR is maybe too loosely exercised by the Judiciary, although the courts are not permitted the power to invalidate an offending statute, unlike, say, Constitutional Law of the USA where an Act of Congress is too intrusive of freedoms guaranteed by the Bill of Rights? This criticism of the HRA and/or the ECHR is especially so from the British tabloid press, where, for example, prisoners have allegedly been granted access to hardcore pornography and suspects in police custody have been given fried chicken - all in the cause of protecting human rights. ${ }^{2}$ But it is not just the tabloid press who have expressed dismay with these measures: it includes Conservative members of the British Coalition government. For example, the Prime Minister, David Cameron, is not known to be a strong supporter of the HRA and/or ECHR, especially when it seemingly strengthens the rights of sex offenders, such as the ruling of the UK Supreme Court in Regina (JF (by his Litigation Friend OF)) v. Secretary of State for the Home Department. ${ }^{3}$ Here the court held that the lifelong requirements on all persons sentenced to 30 months’ imprisonment or more for a sexual offence to notify the police when they moved house or travelled abroad, as per s.82 of the Sexual Offences Act 2003, was a disproportionate interference with Article 8 of the ECHR, the right to private and family life. In response, Cameron said: 'My Honourable Friend speaks for many people in saying how completely offensive it is, once again, to have a ruling...that flies in the face of common sense...We will take the minimum possible approach to this ruling...,4

(JF (by his Litigation Friend OF)) has not been the only ECHR issue which has incurred the wrath of the Prime Minister. What seems to have caused Cameron 
particular ire is the European Court of Human Rights (ECtHR), the European-wide court set up by the ECHR to hear alleged violations of the Convention across the Continent. Famously, in Hirst v. United Kingdom (No.2) ${ }^{5}$ the ECtHR ruled that British law, which does not permit serving prisoners the right to vote, whatever their period of custody, was a disproportionate infringement of Article 3 of the $1^{\text {st }}$ Protocol of the ECHR. Cameron was reported to have said that complying with the judgment made him feel 'physically ill' ${ }^{6}$ And more recently the Prime Minister has added further support to the status quo: 'No-one should be in any doubt. Prisoners are not getting the vote under this government., 7

The Prime Minister is not the only senior Conservative member of the British government to express dissatisfaction with the existing processes of human rights protection in the UK: the Home Secretary, Theresa May, has personally called for the 'scrapping' of the HRA, highlighting the difficulties in, for example, deporting terror suspects. ${ }^{8}$ Indeed, the Home Secretary ridiculed the HRA at the Conservative Party Conference in October 2011 for permitting an illegal immigrant to remain in the UK, because deportation would unjustifiably have prejudiced his rights to Article 8 of the ECHR, the right to private and family life, namely leaving his pet cat! ${ }^{9}$ (It has since been reported that this story was untrue. ${ }^{10}$ ) Furthermore, notwithstanding the constitutional obligation imposed on British government Ministers to uphold the independence of the Judiciary, as per s.3(1) of the Constitutional Reform Act 2005, the Home Secretary, continued the fight against the human rights of some illegal immigrants in a seemingly personal attack on the courts in a recent newspaper article, titled: 'It's my job to deport foreigners who commit serious crime - and I'll fight any judge who stands in my way, says Home Secretary. ${ }^{, 11}$ Here Theresa May claimed that 
the British courts had ignored new immigration rules approved by Parliament. ${ }^{12}$

The apparent contempt shown by senior Conservative members of the government towards the HRA and what it stands for - it seemingly confers rights and privileges on society's 'undeserving': paedophiles, rapists and other sex offenders, terrorists, as well as illegal immigrants - seemingly deflects attention from the Coalition's decision to set up a Commission for a Bill of Rights for the UK in March 2011. The aim of the Commission was to investigate the creation of a British Bill of Rights, incorporating and building on the existing rights and obligations currently provided for by the ECHR. ${ }^{13}$ The Commission published two consultation documents: Do We Need a UK Bill of Rights? ${ }^{14}$ in August 2011 and A Second Consultation ${ }^{15}$ in July 2012. But the issue of a British Bill of Rights, building on the existing rights and duties in the ECHR, was not new. For example, the previous Labour Government, who were the administration responsible for originally enacting the HRA, did explore such an idea in a Green Paper in 2007, ${ }^{16}$ which was tacitly approved by the Parliamentary Joint Committee on Human Rights (JCHR) in $2008 .{ }^{17}$ Nevertheless, the premise of the Conservative partner in the UK Coalition government to set up the Commission for a Bill of Rights was not because they shared the same enthusiasm about the HRA/ECHR as their previous Labour cousins: it was a concession given to the Liberal Democrats, to encourage the latter to join a coalition government with them.

The Commission for a UK Bill of Rights has since published its final report in December 2012: A UK Bill of Rights? The Choice Before Us. ${ }^{18}$ Seven of the Commission's nine members believed that, on balance, there was a strong argument in favour of a UK Bill of Rights on the basis that such a Bill would incorporate and 
build on all of the UK's obligations under the ECHR, and that it would provide no less protection than is contained in the current HRA. But two Commission members were opposed to this conclusion: Helena Kennedy and Philippe Sands. They believed that the majority had failed to identify or declare any shortcomings with the HRA or its application by the courts. They remained open to the idea of a UK Bill of Rights but were concerned that such a move at present might lead to Britain's withdrawal from the ECHR. ${ }^{19}$ In the Commission failing to agree, the press has declared the Conservatives' bid for a UK Bill of Rights 'dead', but still expect the Party to campaign on reform of the HRA and/or the ECHR at the next General Election in $2015 .^{20}$ So for the foreseeable future the existing mechanism for the enforcement of rights in the UK has something of a reprieve, but one must still expect reform to raise its head in the not too distant future. With this in mind it is very much important to recall the legacy of the HRA.

The author has previously written about Articles 2 and 3 of the ECHR, the right to life, and freedom from torture and inhuman and degrading treatment. A particular feature of these rights is that they impose substantive or 'positive' obligations on a state, meaning that death or injury caused by third parties may engage the state if the state has forseen, or at the very least should have forseen, a serious risk of harm to a particular individual and has not acted reasonably in averting it. ${ }^{21}$ The same duty is imposed on a state by Article 4, that is, the state is obliged to prevent a person at risk from being enslaved. The British human rights organisation Liberty argues that in 2008 it represented a young woman who had been held as a slave and had managed to escape her abusive employer, only to face a disinterested police force that refused to 
investigate her allegations of abuse and assault. Until 2010, when s.71 of the Coroners and Justice Act 2009 came into effect, there was no criminal offence in English Law of holding someone in slavery or servitude or compelling them to perform forced or compulsory labour. Liberty says: 'Thank goodness for the HRA. Following the [young woman's] case, and using Article 4...Liberty and other organisations lobbied hard...for the creation of a new serious criminal offence of slavery or servitude... ${ }^{22}$

If the HRA had not been enacted (or at the very least the ECHR not been ratified by the UK in international law), permitting British people the enforcement of these human rights before their domestic courts, would the UK have been immune from its substantive duty to prevent infringements of slavery and servitude? These new criminal offences, if they are directly attributable to the UK honouring its responsibilities under Article 4, are surely indicative of the success of the HRA, and the ECHR rights it guarantees? For this reason the author in this two article study is continuing to further his research into the positive obligations imposed on a state by the ECHR - but from the perspective of slavery, servitude and forced labour. In this first article he considers the substantive duties imposed on the UK by Article 4 in implementing statutory measures to, say, criminalise slavery; in so doing, he intends to present a defence of the much criticised HRA/ECHR.

In the second, later article the author intends to assess again the degree to which Britain is in fact complying with its substantive duties to prevent slavery, servitude and forced labour, but with particular reference to the UK's non-legislative measures, such as the National Referral Mechanism (NRM), the identification procedure 
established as part of the Council of Europe's Convention on Action Against Trafficking in Human Beings to help identify victims of the modern day slavery practice of human trafficking. In 2006, when examining the then UK arrangements for preventing trafficking, the JCHR said that whilst many would agree that the Government had started taking some significant steps in preventing the crime, it considered that the current level of protection provided to victims as a whole was still 'far from adequate'. ${ }^{23}$ In the period between, for example, the JCHR report in 2006 and the present day, what measures, other than legislative ones, have the UK introduced to comply with its positive obligations arising from Article 4 of the ECHR? Assessing whether Britain has been successful in introducing initiatives of a non-statutory nature, to combat slavery and forced labour, including human trafficking, will, therefore, be the focus of a second, later article in this study. Here, in this piece, there is an intention to evaluate the UK's legislative measures. But first it is important to discuss the human right in question, the freedom from slavery, servitude and forced labour. This is the purpose of the next section.

\section{Slavery, servitude, forced and compulsory labour}

When one speaks of slavery there is an automatic impression of the slave trade - the triangular transatlantic route between Europe, Africa and the Americas - which was in operation internationally from the mid- $17^{\text {th }}$ Century; and finally abolished - at least in terms of participation by the British - in the early $19^{\text {th }}$ Century. The trade was responsible for the enslavement of over three million West Africans in the Americas. 
The slave ships' infamous 'Middle Passage' - the central voyage across the Atlantic Ocean from Africa - was particularly cruel:

'Enslaved Africans were packed in unbelievably hot, cramped conditions in the hold of the ship. They were kept below decks; men, women and children separated. The men were usually kept shackled, hand-cuffed in pairs by their wrists and with iron leg-rings riveted around their ankles. Frequently they had so little space they could only lie on their sides. They could not sit or stand up: headroom was only 2 feet 8 inches $(68 \mathrm{~cm})$...The physical conditions, fear and uncertainty left many totally traumatised and unable to eat...Beatings and brandings were common, as was the abuse of the women by the ships' crews. The journeys could last up to six weeks and sometimes more...Disease and brutality took its toll: between one tenth and one quarter of the enslaved Africans died on every journey. ${ }^{24}$

The British trade in slaves was abolished by the Slave Trade Act 1807 but enslavement itself was not outlawed in Britain's colonies until the Slave Trade Abolition Act 1833. This was nearly 200 hundred years ago. In 2005 the International Labour Organisation (ILO) published its first global estimate of forced labour. It estimated that over 12 million people worldwide were in forced labour at any point in time in the period 1995-2004, meaning that this figure was only a minimum. ${ }^{25}$ The ILO has since revised this estimate for the period 2002-2011, believing the number is now nearly 21 million. ${ }^{26}$ Of these, 18.7 million (90\%) are exploited in the private 
economy: 4.5 million for reasons of sexual exploitation and 14.2 million for reasons of labour exploitation, in areas such as agriculture, construction, domestic work and manufacturing. ${ }^{27}$ The remaining 2.2 million (10\%) are in state-imposed forms of forced labour; for example, in prison conditions which contravene ILO standards, or in work imposed by the state military or by rebel armed forces. ${ }^{28}$

People particularly susceptible to forced labour are often the most vulnerable in society. In the UK they are invariably recruited in benefit offices, soup kitchens and other places frequented by alcoholics, the homeless or those with little or no family support, and told they will be given work, clothing, a home and food. ${ }^{29}$ The labour is coerced because often those in these situations have an irregular immigration status, fearful that their 'employers' will inform the authorities. They could have also been threatened with violence against themselves and/or their family. ${ }^{30}$ Over time there often becomes an emotional dependency and institutionalisation. ${ }^{31}$ Typical features of people in circumstances of forced labour include: dirty and unsafe working conditions, including a lack of protective clothing; long working hours; unrealistic employment targets; under or non-payment; and more seriously, intimidation, threats, bullying, as well physical and/or sexual violence. Often forced labour includes social isolation and detention, ${ }^{32}$ which can be in appalling conditions such as confinement to small rooms such as lofts or cellars, invariably sleeping on cold, damp floors. ${ }^{33}$ The health and welfare of those in forced labour is likely to be poor, too, because of, for example, malnourishment. ${ }^{34}$ 


\section{International Legal Responses to slavery, servitude and forced labour}

The freedom from slavery, servitude and other forms of forced labour is protected in several international human rights instruments; for example, Article 4 of the Universal Declaration on Human Rights (UDHR) states: 'No one shall be held in slavery or servitude; slavery and the slave trade shall be prohibited in all their forms.' This is similar wording to Article 8(1) of the International Covenant on Civil and Political Rights (ICCPR). Regionally, there is the ECHR, for example; Article 4(1) of the ECHR prohibits slavery and servitude. This freedom is 'absolute', meaning there are no limitations (unlike, say, Article 10(1) of the ECHR, the freedom of expression, which can be infringed for the purposes of, say, the prevention of disorder and crime, assuming that the infringement is in proportion to the objective, as per Article 10(2)). Significantly, freedom from slavery is also 'non-derogable', as per Article 15(1) of the ECHR, meaning it can never be suspended in times of war or public emergency threatening the life of the nation. Article 4(2) of the ECHR also outlaws forced or compulsory labour. But interestingly Article 4(3) excludes: (a) any work done in the ordinary course of lawful detention; (b) compulsory military service; (c) any service done in an emergency or calamity threatening the life or well-being of the community; and (d) any work or service which forms part of normal civic obligations.

The serious nature of slavery is such that it deserves its own convention: the Slavery Convention, signed in 1926. According to Article 1(1), slavery is defined as: ‘...the status or condition of a person over whom any or all of the powers attaching to the 
right of ownership are exercised.' This definition focuses on the notion of 'ownership', the idea that a person can be bought and sold. (But, nowadays, the element of ownership, or rather 'powers attached to the right of ownership', no longer require the acquisition of a person for money or some other value. ${ }^{35}$ ) Like Article 4(3) of the ECHR, Article 5(2) of the Slavery Convention permits forced or compulsory labour in limited circumstances: '[The] labour shall invariably be of an exceptional character, shall always receive adequate remuneration, and shall not involve the removal of the labourers from their usual place of residence.' Slavery and the slave trade are arguably crimes under customary international law, too, perhaps reaching the level of a 'peremptory norm' (jus cogens), meaning even those states who have not ratified the 1926 Convention are obliged to prosecute alleged perpetrators or at the very least turn them over to another state for prosecution.

The Slavery Convention was supplemented in 1956: Supplementary Convention on the Abolition of Slavery, the Slave Trade, and Institutions and Practices Similar to Slavery. Whereas the original 1926 Convention defined only 'slavery', the Supplementary Convention defined 'servitude', or in its terms 'servile status'. A person in 'servile status', as per Article 1, includes: 'debt bondage' - 'the status or condition arising from a pledge by a debtor of his personal services... as security for a debt, if the value of those services...is not applied towards the liquidation of the debt or the length and nature of those services are not respectively limited and defined' and 'serfdom' - 'the condition or status of a tenant who is...bound to live and labour on land belonging to another person and to render some determinate service to such other person, whether for reward or not, and is not free to change his status.' 
There are also international conventions dedicated to the elimination of forced or compulsory labour such as the ILO’s Convention Concerning Forced or Compulsory Labour (No.29), 1930. Article 2(1) defines forced or compulsory labour, which contains three main elements: first, some form of work or service must be provided; second, the work is performed under the threat of a penalty, which can be for example physical, psychological or financial; and third, the work is undertaken involuntarily, meaning that the person either became engaged in the activity against their free will or, once engaged, finds that they cannot leave the job. Like the ECHR there are some exceptions, as per Article 2(2) of this Convention. These are similar in nature to Article 4(3) of the ECHR.

The issue of slavery and servitude was addressed by, for example, the ECtHR in Siliadin v. France. ${ }^{36}$ Here the court found that a 16 year old Togolese national, working involuntarily as an unpaid household servant lasting 15 hours a day, seven days a week, had not been held in slavery in the traditional sense: 'Although the applicant was, in the instant case, clearly deprived of her personal autonomy, the evidence does not suggest that she was held in slavery in the proper sense, in other words that Mr and Mrs B. exercised a genuine right of legal ownership over her, thus reducing her to the status of an 'object'” ${ }^{37}$ However, the ECtHR did rule that the applicant had been held in servitude. ${ }^{38}$ Servitude was linked to the concept of slavery and was a particularly serious form of deprivation of liberty, involving an obligation to provide one's services under coercion, to live on the property of another and being unable to change one's situation. ${ }^{39}$ 


\section{The positive nature of freedom from slavery, servitude and forced labour}

Very much like other fundamental rights such as the right to life and freedom from torture, states must not only refrain from infringing freedom from slavery, that is, the right acts 'negatively', but take measures to prevent its violation, meaning the right also acts 'positively'. For example, Article 2 of the 1926 Slavery Convention obliges state parties: (a) to prevent and suppress the slave trade; and (b) to bring about, progressively and as soon as possible, the complete abolition of slavery in all its forms. Article 5 of the same Convention also obliges state parties to take all necessary measures to prevent compulsory or forced labour from developing into conditions analogous to slavery. Using similar language to Article 5, Article 1 of the 1956 Supplementary Convention obliges all state parties to take all practicable and necessary legislative and other measures to bring about progressively and as soon as possible the complete abolition or abandonment of servitude. Similarly, the ILO is responsible for conventions whose purpose is to impose positive duties on states to prevent forced and compulsory labour, such as: Convention Concerning Forced or Compulsory Labour (No.29), 1930 and Convention Concerning the Abolition of Forced Labour (No.105), 1957. In reference to the former, Article 1 says that each member state undertakes to suppress the use of forced or compulsory labour in all its forms within the shortest possible period. One way of fulfilling a state's responsibilities to eradicate slavery, servitude etc is to criminalise the practice. For example, Article 6(1) of the 1956 Supplementary Slavery Convention states: 'The act of enslaving another person... or of attempting these acts, or being accessory thereto, or being a party to a conspiracy to accomplish any such acts, shall be a criminal offence under the laws of the States Parties to this Convention...' 
Regionally, the ECtHR has discussed the positive duties imposed on states to prevent violations of fundamental rights of the ECHR on several occasions. Of particular note is Article 2(1) of the ECHR, which is explicit in the substantive obligation it imposes on states to protect life: 'Everyone’s right to life shall be protected by law.' This duty was considered by the ECtHR at length in the case of Osman v. United Kingdom. ${ }^{40}$ There the court said:

'The Court notes that the first sentence of Article 2(1) enjoins the State not only to refrain from the intentional and unlawful taking of life, but also to take appropriate steps to safeguard the lives of those within its jurisdiction. It is common ground that the State's obligation...extends beyond its primary duty to secure the right to life by putting in place effective criminal law provisions to deter the commission of offences against the person backed up by lawenforcement machinery for the prevention, suppression and sanctioning of breaches of such provisions. ${ }^{41}$

Nevertheless, this positive obligation imposed on a state to prevent violations of the right to life by third parties is not limitless:

'For the Court, and bearing in mind the difficulties involved in policing modern societies, the unpredictability of human conduct and the operational choices which must be made in terms of priorities and resources, such an obligation must be interpreted in a way which does not impose an impossible or disproportionate burden on the authorities. Accordingly, not every claimed 
risk to life can entail for the authorities a Convention requirement to take operational measures to prevent that risk from materialising. ${ }^{, 42}$

For the court to find a breach of a state's positive duty to protect life it must be established that 'the authorities knew or ought to have known... of the existence of a real and immediate risk to the life of an identified individual or individuals from the criminal acts of a third party and that they failed to take measures within the scope of their powers which, judged reasonably, might have been expected to avoid that risk. ${ }^{43}$ That is, it is sufficient for an applicant to show that the authorities did not do all that could have been reasonably expected of them, to avoid a real and immediate risk to life of which they had, or ought to have had, knowledge. ${ }^{44}$

These principles of ECHR law apply equally to other fundamental human rights such as freedom from slavery. This was confirmed by the ECtHR in Siliadin. ${ }^{45}$ Indeed, an effective deterrent could only have been achieved by criminal-law provisions, the court in Siliadin stated. ${ }^{46}$ In respect of the specific facts of that case the court observed that the applicant's 'employers' were prosecuted under the then Articles 225-13 and 225-14 of the French Criminal Code, which had made it an offence to exploit an individual's labour and to submit him or her to working or living conditions that were incompatible with human dignity. ${ }^{47}$ The defendants were then sentenced to twelve months' imprisonment, seven of which were suspended, and ordered to pay a fine of FRF 100,000 each and to pay, jointly and severally, FRF 100,000 to the applicant in damages. ${ }^{48}$ But these offences, and subsequent punishments, were insufficiently robust to protect the applicant from abuse. ${ }^{49}$ Following the ruling of the ECtHR in Siliadin it was noted: '[Countries] will be expected, in order to fulfil their positive 
obligations under Article 4, to establish adequate and clear criminal offences in relation to forced labour practices....and to impose appropriate sentences. ${ }^{50}$

One of those countries where it was argued that the law did not adequately protect people was the UK: 'The judgment [in Siliadon] suggests that the UK is now in breach of its obligations under Article 4, since...neither slavery, nor servitude or forced or compulsory labour are currently criminal offences. ${ }^{51}$ This suspicion was later confirmed in the case of $C N$ v. United Kingdom, ${ }^{52}$ where the ECtHR ruled that the legislative framework in place, prior to the enactment of offences contrary to s.71 of the Coroners and Justice Act 2009 (see more below), had been insufficient to afford practical and effective protection against the violations of Article 4 by third parties. ${ }^{53}$ The court also found that there had been an inadequate investigation by the British authorities, such as the London Police’s Human Trafficking Team, of a credible complaint of domestic servitude by the applicant, who had fled Uganda to escape sexual and physical violence and been forced to work as a live-in carer for an elderly couple. ${ }^{54}$ This case therefore also confirmed that there was a corresponding procedural duty imposed on a state, arising from its positive obligation, to investigate suspected violations of Article 4, a process that was well established in the jurisprudence of other fundamental rights of the ECHR, such as Article 2, the right to life. ${ }^{55}$ 


\section{Human Trafficking}

A contemporary form of slavery is human trafficking. This is thought to be the world's fastest growing criminal activity involving a global enterprise worth in the region of US $\$ 32$ billion, of which 2.4 million people are thought to be its victims. ${ }^{56}$ Human trafficking involves the movement of a person from one place to another into conditions of exploitation, using, for example, deception. ${ }^{57}$ According to Article 3(a) of the United Nations Protocol to Prevent, Suppress and Punish Trafficking in Persons, Especially Women and Children, that is, the 'Palermo Protocol', human trafficking is defined as: 'The recruitment, transportation, transfer, harbouring or receipt of persons, by means of the threat or use of force or other forms of coercion, of abduction, of fraud, of deception, of the abuse of power or of a position of vulnerability...for the purpose of exploitation.' (Exploitation includes sexual exploitation, forced labour, slavery, servitude or the removal of organs.) Human trafficking has therefore three constituent elements: a movement; a control; and a purpose - the exploitation of a person. ${ }^{58}$ Although human trafficking often involves an international cross-border element, it is possible to be a victim of human trafficking within one's own country. ${ }^{59}$

Trafficking is to be contrasted with 'human smuggling'. The latter involves, according to Article 3 of the United Nations Protocol Against the Smuggling of Migrants by Land, Sea and Air, the 'procurement, in order to obtain, directly or indirectly, a financial or other material benefit, of the illegal entry of a person into a 
State Party of which the person is not a national or a permanent resident'. So human smuggling involves the transportation of willing migrants in search of, maybe, better economic opportunities, whilst trafficking has a more sinister and exploitative purpose; a trafficked person's initial consent to be moved has been vitiated by fraud, for example. Thus, whilst both practices are illicit - assisting a person's unlawful immigration into a Member State of the European Union (EU), such as the UK, is an offence contrary to s.25 of the Immigration Act 1971, for example - there is a key difference, principally arising from a smuggled person's full and informed consent to be transported. (Importantly, however, a person could start out as being smuggled, only to become trafficked if their circumstances tragically change. So the two practices can be very similar in nature. ${ }^{60}$ )

In the case of Rantsev v. Cyprus and Russia, ${ }^{61}$ where the victim had been trafficked from Russia to Cyprus for reasons of sexual exploitation, the ECtHR likened trafficking to slavery; the ECHR was a living instrument to be interpreted in modern day conditions. ${ }^{62}$ The court noted that, like slavery, trafficking in human beings, by its very nature and aim of exploitation, was based on the exercise of powers attaching to the right of ownership; it treated human beings as commodities to be bought and sold and put to forced labour, often for little or no money; it implied close surveillance of the activities of victims, whose movements were often circumscribed; and it involved the use of violence and threats against victims, who lived and worked under poor conditions. $^{63}$ 
Very much like other forms of slavery and forced labour, the 'Palermo Protocol' emphasises a substantive obligation on states to take positive measures to avert human trafficking. For example, Article 2 states that the purpose of the Protocol is - (a) to prevent and combat trafficking in persons; (b) to protect and assist the victims of such trafficking, with full respect for their human rights; and (c) to promote cooperation among States Parties to meet those objectives. One way of preventing trafficking is to introduce domestic measures outlawing the practice. In this respect, Article 5 obliges state parties to criminalise trafficking. Moreover, Article 6, which is described as 'assistance to and protection of victims of trafficking', notes that a trafficked person is a victim rather than an accessory to the trafficking. And Article 7 encourages states to allow victims of trafficking to remain in their country of transit if they so wish.

In addition to international documents outlawing human trafficking, there are regional human rights documents preventing the practice, too, such as the Council of Europe's Convention on Action against Trafficking in Human Beings. Article 4 adopts the same definition of human trafficking as that contained in Article 3 of the Palermo Protocol, and Article 1 of the Convention has similar purposes to Article 2 of the Palermo Protocol. There are further provisions in the Convention emphasising the positive nature of the right, such as Article 5(2) which obliges state parties to establish and/or strengthen effective policies and programmes to prevent trafficking, as well as Articles 10 and 12 addressing victim protection. Much like Article 6 of the Palermo Protocol, Article 18 of the Convention imposes obligations on state parties to criminalise trafficking. Regionally, there is also an EU Directive on Trafficking: Preventing and Combating Trafficking in Human Beings and Protecting its Victims. ${ }^{64}$ 
In the case of Rantsev, ${ }^{65}$ which was referred to above, the ECtHR discussed states' substantive duties to prevent trafficking. To fulfil the positive nature of their obligations, states must: (1) adopt criminal law measures to punish traffickers; (2) put in place appropriate legal and administrative frameworks to prevent people becoming victims of trafficking; (3) take protective operational measures when it is demonstrated that the State authorities were aware, or ought to have been aware, of circumstances giving rise to a credible suspicion that an identified individual has been, or was at real and immediate risk of being, trafficked or exploited; (4) investigate situations of trafficking; and (5) cooperate in cross-border trafficking cases. $^{66}$

In specific reference to the 'operational duty' element of Article 4 (see point 3 above in Rantsev), that is, authorities were aware, or ought to have been aware, of circumstances giving rise to a credible suspicion that an identified individual has been, or was at real and immediate risk of being, trafficked or exploited, this is of course an elucidation of the test developed by the ECtHR in the Article 2 case of Osman (see above), or was it? Following Osman, this 'operational duty' test has two criteria: (1) a 'knowledge' element (point 3 above) and (2) a ‘due diligence' element, which demands doing what reasonably could have been expected to avoid the foreseeable risk. ${ }^{67}$ Stoyanova argues that the original test established in Osman was modified in Rantsev (making the test less demanding?), that is, a new 'knowledge' element was added: 'a credible suspicion' that an identified individual was trafficked. So, it is not necessarily required now that the authorities knew, or ought to have known, of the existence of a real and immediate risk - only perhaps in circumstances where there was a risk of being trafficked (rather than a situation where a person was 
suspected of having been trafficked). Stoyanova states that the Court did not explain where the standard of ‘credible suspicion’ came from; neither did it give any hints as to why exactly this standard was endorsed. ${ }^{68}$

In applying these five principles of law to the facts of the case, the ECtHR in Rantsev found that Cyprus and Russia had failed in their duties to prevent violations of Article 4. The court concluded that Cyprus had violated its positive obligations on two counts: first, the failure of the Cypriot police to take operational measures to protect the victim, Ms Rantseva, since circumstances had given rise to a credible suspicion that she had been a victim of trafficking; ${ }^{69}$ secondly, and more broadly, Cyprus' failure to put in place an appropriate legal and administrative framework to combat trafficking generally as a result of the then regime of 'artiste visas' ${ }^{70}$ That is, the Cypriot authorities must have been aware of the problem of trafficking for sexual exploitation in their country, and when the victim was brought to their attention they should have recognised a risk and taken steps to protect her. ${ }^{71}$ Does this widen the state's positive duty again, in that fulfilling the 'knowledge element' of the 'operational duty' test, states must also have regard to circumstances in their respective countries which are particularly susceptible to human rights abuses, like the Cypriot artiste visa?

'Article 4 obliges states to prosecute and penalise effectively anyone who has engaged in acts aimed at holding another in slavery, servitude or forced labour. In Rantsev the court went further...The obligation is no longer confined to the criminal law, as required by Siliadin. It addresses victims and potential victims... States cannot turn a blind eye to businesses that act as 
fronts for trafficking; furthermore, they must look at their own immigration rules to see whether they are in line with the protective function of Article 4 for instance, in the Rantsev case, one problem was that the Cypriot visa regime in force at the time made it relatively easy for the employer to control and exploit the foreign worker. ${ }^{, 72}$

Moreover, in Rantsev Russia was in breach of Article 4 on account of its failure to investigate how and where the victim had been recruited and, in particular, to take steps to identify those involved in her recruitment or the methods of recruitment used. ${ }^{73}$ Rantsev was undoubtedly, therefore, a significant case in terms of Article 4. Not only was Cyprus liable for failing to prevent violations of this human right, it being the destination state, but Russia was culpable, too, to some degree, as the source state. Thus, this case emphasised the transnational nature of human trafficking and the obligations imposed on states by international human rights law to cooperative effectively in its prevention.

\section{UK Laws outlawing Slavery and Forced Labour, including Trafficking}

Britain has a range of statutes outlawing slavery, servitude and forced labour, including human trafficking. Participating in the slave trade, that is, dealing in slaves, or exporting or importing slaves, is an offence under s.10 of the Slave Trade Act 1824. More recently, the Sexual Offences Act 2003 criminalises trafficking into the UK, within the UK, and out of the UK for the purposes of sexual exploitation: ss.5759 respectively. These offences, which came into force in the UK in May 2004, attract 
a maximum sentence of 14 years' imprisonment. And, assuming a person arranges or facilitates the arrival into the UK of an individual, the Asylum and Immigration (Treatment of Claimants, etc.) Act 2004 criminalises trafficking into the UK, within the UK, and out of the UK - ss.4(1), 4(2) and 4(3) respectively - for reasons other than sexual abuse such as exploitation for labour, organ removal or benefit fraud. These offences, which came into force in the UK in December 2004, also attract a maximum sentence of 14 years’ imprisonment.

A further offence which criminalises holding another person in slavery or servitude or requiring them to perform forced or compulsory labour was introduced by the Coroners and Justice Act 2009, s.71(1). This and came into force in the UK in April 2010 and carries a maximum sentence of 14 years' imprisonment. It was introduced after intense lobbying by human rights groups such as Liberty and Anti-Slavery International. Campaigners argued that too many loopholes existed in British law before 2009 because of the need to prove a person had also been trafficked, for example. The campaign to introduce this offence also intensified after 23 Chinese cockle pickers drowned in Morecambe Bay, Lancashire, in $2004 .^{74}$ The latter incident was also significant in producing legislation of its own: the Gangmasters (Licensing) Act 2004. Section 1 of the Act established the Gangmasters Licensing Authority, which, according to s.3, is responsible for setting up and operating a licensing scheme for those providing employment in agriculture, shellfish gathering and the processing and packaging sectors. ${ }^{75}$ Sections 6 and 12 prohibit anyone from acting as a gangmaster without a licence. $^{76}$ 


\section{Assessing UK Law's Compliance with the Positive Duty of Article 4}

The HRA came into effect in October 2000, enshrining Article 4 of the ECHR, the prohibition on slavery, servitude and forced labour, into UK law. This not the only success of the HRA. Of course this statute has many achievements but word limitations, alas, do not permit the author to discuss all of these here, so the reader may wish to see, for example: Liberty, The Human Rights Act: What's Not to Love? ${ }^{77}$ Nevertheless, what is particularly important about the HRA are the fundamental rights of the ECHR - the right to life, freedom from torture and freedom from slavery - it incorporates into domestic law. Yes, their very significance as basic human rights is important, but what also makes them particularly special is their positive nature, that is, the substantive duties they impose on states to prevent violations, especially by third parties. Without the HRA, and the ECHR rights it enshrines, coupled with the jurisprudence of the ECtHR such as Siliadin, the UK probably would not have had an offence of holding a person in slavery or servitude or requiring them to perform forced or compulsory labour. It will be recalled that in the case of $C N^{78}$ the ECtHR ruled that Britain's legislative framework in place prior to s.71 of the Coroners and Justice Act 2009 was insufficiently robust to afford practical and effective protection against violations of Article 4. In argument, the UK Government had claimed that the then criminal offences were adequate. Nevertheless, the ECtHR ruled that someone like CN, who had been subjected to domestic servitude, but was not a victim of trafficking, was left without any assistance or remedy. ${ }^{79}$ Thus, if this situation had continued, there would not have been the successful convictions of various members of the Connors family - Tommy Snr, James John, Patrick and Josie Connors -at Luton Crown Court in July 2012. 
The Connors controlled, exploited, verbally abused and beat their victims at a caravan site near Leighton Buzzard in Bedfordshire. They coerced their victims into working for their block paving business. The victims were given little food, forced to wash in cold water and paid little or no money for working up to 19 hours a day, six days a week. They lived in caravans and sheds deemed unfit for human habitation and spent Sundays doing further work by way of door-to-door selling. ${ }^{80}$ James John and Josie Connors were sentenced to 11 and four years respectively. ${ }^{81}$ At a separate trial in May 2013, the jury failed to reach verdicts on other charges against Tommy Snr and Patrick Connors. Tommy Snr and Patrick were then sentenced to eight and five years respectively for their convictions, with James John and Josie Connors, from the previous year. ${ }^{82}$ Surely the successful convictions of the Connors family under s.71 of the Coroners and Justice Act 2009, arguably because of the UK's obligations to take effective measures preventing violations of Article 4 of the ECHR, is a strong defence of the HRA?

But this legislation is not without criticism; there is a particular difficulty in establishing the existence of coercion, for example. In this respect, Mantouvalou argues:

'Modern slaves are not held in chains - not literally. Are they actually free to work in extremely poor conditions if their only alternative is extreme socioeconomic deprivation or deportation? Because of the lack of explicit physical force, it might be argued that there is nothing coerced in these situations...if they are not locked up in the employer's home or business premises. ${ }^{83}$ 
This is a view shared by the UK's Equality and Human Rights Commission (EHRC) in its 2012 British Human Rights Review. ${ }^{84}$ Whilst the EHRC largely believed that the current domestic legislative framework to criminalise forced labour had complied with the relevant human rights obligations to prohibit the practice, ${ }^{85}$ it argued that prosecuting cases was challenging. It could be very difficult to distinguish between bad conditions at work and a situation which actually had constituted forced labour. Therefore, when agencies came across bad conditions they were unsure whether the situation should be dealt with in an employment tribunal or by a criminal prosecution. In the EHRC's opinion, the Coroners and Justice Act has not helped to clarify this distinction: 'All [the statute] says is that it is an offence to 'require another person to perform forced or compulsory labour' - it does not define these terms. There is, therefore, a risk that the Act will not deter perpetrators or lead to effective prosecutions. $^{\text {86 }}$

The EHRC further noted: by the end of 2010, there had only been 107 convictions for trafficking under the Sexual Offences Act 2003, and 22 convictions for trafficking under the Asylum and Immigration (Treatment of Claimants) Act $2004 .^{87}$ (In 2011 the convictions rates for these two offences were 8 and 0 respectively. ${ }^{88}$ ) The EHRC argued that the 'new' offences would not sufficiently deter offenders for this reason either. ${ }^{89}$ A view recently shared by a specialist in this area: 'The risks for criminals are still too low and the benefits for them in terms of money are still high. That balance needs to be addressed. ${ }^{90}$ Why might organised criminals make a conscious decision to, say, traffic humans rather than, say, drugs or weapons? One argument may be the sentencing regimes in Britain for these offences. ${ }^{91}$ The minimum and maximum sentences for human trafficking are 12 months and 14 years respectively, 
whereas the minimum and maximum sentences for drug trafficking are 2 years and life respectively; and the minimum and maximum sentences for arms trafficking are 5 years and life respectively. The low risks for criminals involved in human trafficking can then have demotivating effects on the investigating authorities. One example is 'Operation Ruby' which focused on a leek farm in Northamptonshire in 2008. Some 200 police officers targeted 21 premises, arresting 13 people, who were later charged. ${ }^{92}$ The authorities spent three years building a case - and yet there were no convictions:

'It was a signal, heard by every police force in the country, that going after a suspected immigrant ring is one of the most expensive and potentially fruitless exercises in modern policing. Some of the officers later [said]...that the cost of the operation "crippled the entire unit". They might have secured convictions, they said, “if the legislation was there”. But it isn't, not properly. The Connors convictions were under the Coroners and Justice Act 2009...But this is only one of the three types of offence under which a case may fall: sometimes, it is treated as an immigration issue; sometimes, as a sex crime. The police complain that they are not sure what type of conviction they are looking for, or what evidence they need for it. Indeed, many trafficked women still face being arrested themselves, rather than being treated as victims. ${ }^{93}$

Britain's legislative responses to slavery, servitude and forced labour, including human trafficking, could be improved, there is no doubt; one way of doing so is maybe to address the sentencing regime. Is this sufficiently preventative to discharge the UK's substantive obligation under Article 4 of the ECHR, especially when 
compared to, say, the minimum and maximum sentences for trafficking in drugs and arms? Perhaps the sentencing regime for human trafficking is not the problem, but the actual sentences being imposed on those found guilty is? In fact, the average sentence for human trafficking in the UK is 4.7 years. ${ }^{94}$ A typical case is this:

'A former hospital director has been ordered to pay £25,000 to an African woman she kept as a slave in London. Mwanahamisi Mruke was flown from Tanzania in 2006 and made to work 18-hour days for Saeeda Khan at her home in London. The judge at Southwark Crown Court, who also gave her a suspended nine-month prison term, said she was guilty of "the most appalling greed”... “I felt like a fool, I was treated like a slave,” Ms Mruke said. The court heard how Khan fed Mruke two slices of bread a day and ordered her around by ringing a bell she kept in her bedroom. Ms Mruke was banned from leaving the house and never learned English because the family watched Pakistani TV. Beginning work at 6am, she would often not be allowed to rest before midnight as she cleaned, gardened, cooked meals and accompanied Khan's disabled son on walks. ${ }^{95}$

Was a fine of $£ 25,000$ and a suspended nine-month prison term sufficiently serious to reflect the degree of abuse by the defendant against the victim, especially since the judge actually trying the case described the defendant as being guilty of the 'most appalling greed'? Indeed, was this sufficiently punitive to act as a deterrent against others involved in similar criminal acts? 
Another outcome from 'Operation Ruby' was the apparent confusion shown by the investigating authorities in dealing with the case, that is, was it a criminal matter or an immigration one? The British human rights organisation, the Centre for Social Justice (CSJ), believes the UK needs a modern Slavery Act. ${ }^{96}$ It states that legislation relating to human trafficking and modern slavery currently lies under three different Acts: the Sexual Offences Act 2003, the Asylum and Immigration (Treatment of Claimants) Act 2004 and the Coroners and Justice Act 2009. ${ }^{97}$ Then, confusion caused by this separation is compounded by the fact that offences of human trafficking for nonsexual exploitation fall under immigration law: ${ }^{98}$ 'This separation is unhelpful, and creates unnecessary confusion for those whose job it is to implement the legislation. It also perpetuates the misunderstanding of modern slavery as primarily an immigration - not a criminal - problem. This holds our country back. ${ }^{99}$ Part of the problem, the CSJ argues, is that the responsibility in government for this area lies with Britain's Minister for Immigration. Modern slavery is a crime and not an immigration issue, so the remit should be transferred to the Minister for Policing and Criminal Justice. ${ }^{100}$

It must be recalled, however, that without the HRA, and the ECHR rights it enshrines in domestic law, the Connors family probably would have been immune from prosecution because of the lack of movement of their workers (notwithstanding possible alternative charges for violence, in that they assaulted some of their victims). In sentencing two of the defendants, James John Connors and Josie Connors, the judge, HHJ Michael Kay QC, said:

'The homeless, addicted and isolated men who sleep rough and beg on the streets were potential workers who could be exploited for financial gain...The 
promise of pay in return for work was a monstrous and callous deceit...to entice the men to enter the travellers' site, at which point more insidious methods of control and manipulation could be utilised to keep them in servitude and exact forced labour. Primarily the methods used...were brutality and intimidation. Assaults by way of punches, kicks, slaps or beatings with a weapon were committed to mark disapproval of insubordination or what was deemed to be an unacceptable standard or speed of work or to emphasise the hierarchy of control...Threats were made of grave and even life threatening consequences if a worker sought to leave. As well as using physical means to keep workers in servitude, the defendants also acted towards them so as to apply and maintain psychological pressure. In order to increase their sense of isolation, to strip them of their identity and degrade them, a number of measures were employed. There was verbal abuse on a regular basis. They were sworn at and called names which demeaned them. There were not permitted to have any money. Identity or private documents were removed and destroyed. They were housed in accommodation which was markedly inferior to that enjoyed by the defendants and at times was unsuitable for human habitation...Clothes were confiscated and thrown away. In some cases...their heads were shaved...The [Connors] complete disdain for the dignity and fundamental rights of their fellow human beings is shocking.' ${ }^{101}$

In its 2011 Human Trafficking Strategy, the British Government undertook to review its trafficking legislation to ensure the effective deterrence, disruption and prosecution of offenders. ${ }^{102}$ An internal review was conducted some months later. This review 
was published in 2011 and identified three areas where the UK's legislation could be strengthened. At the time new laws were already being introduced in two of these areas: to criminalise human trafficking committed by British nationals anywhere in the world; and to criminalise human trafficking for purposes of non-sexual exploitation which had taken place wholly within the UK. ${ }^{103}$ (These were to comply with the UK's obligations in Article 10(1) of the EU Directive on Trafficking.) Sections 109 and 110 of the Protection of Freedoms Act 2012 have since outlawed these two situations. The former - a UK national committing human trafficking abroad for reasons of sexual exploitation - contains extremely broad provisions and has a wide extra-territorial reach. ${ }^{104}$ The latter - a UK national committing human trafficking abroad, and within the UK for reasons of non-sexual exploitation - goes further than, say, s.4 of the Asylum and Immigration (Treatment of Claimants, etc.) Act 2004, in that there a person must first arrange or facilitate a person's entry into Britain. The third area identified by the UK's legislative review related to unduly lenient sentences. At present only offences of trafficking for sexual exploitation, as per s.36 of the Criminal Justice Act 1988, can be referred by Britain’s Attorney General to the Court of Appeal for consideration, where it appears to him or her that a court of first instance has passed an unduly lenient sentence. The Government stated that it would correct this anomaly. ${ }^{105}$

Earlier the UK's minimum and maximum sentences for human trafficking were questioned. However, the maximum sentence for human trafficking, which is 14 years, compares favourably with, say, the EU Directive on Trafficking which sets 10 years’ imprisonment, as per Article 4(2), as a minimum maximum sentence. Indeed 
the maximum sentences in comparable countries - Germany and Sweden, for example - are less than the UK's: 10 years.

In concluding its statutory review of trafficking legislation, the UK Government did not believe that wholesale change to legislation was required. Whilst introducing a new human trafficking bill to consolidate existing legislation into one Act would have been administratively neater (perhaps along the lines of the CSJ's call for a modern Slavery Act?) the report did not find this was necessary: ${ }^{106}$ 'To rely solely on prosecuting and convicting the perpetrators means that we have failed to tackle the core issue, protecting the vulnerable people who are susceptible to traffickers in the first place. ${ }^{107}$

\section{Conclusion}

As far back as 2006 the JCHR broadly agreed that the then legislative framework to prohibit and criminalise human trafficking in the UK had complied with relevant human rights obligations. ${ }^{108}$ But what of situations where a person had allegedly been enslaved but there was no, or little evidence, that they had been trafficked? In Siliadin the ECtHR held that France had been in violation of its positive duty to prevent violations of Article 4 of the ECHR, by insufficiently deterring the domestic abuse of a young girl from Togo. Later, therefore, the UK enacted s.71 of the Coroners and Justice Act 2009 criminalising holding a person in slavery and servitude or compelling a person to perform forced or compulsory labour, thus making it ECHR compliant (as confirmed by the subsequent case of $C N$ at the ECtHR). This new offence is surely a success of the HRA, and the ECHR rights it introduces into British 
law, especially those of a fundamental nature such as Article 4 where there is a further duty imposed on a state to prevent their abuse by non-state actors. (And let us not forget the corresponding procedural obligation to investigate their alleged violations.) Without the ECHR, and the legislation permitting enforcement of this Convention in the UK, holding a person either in slavery or servitude, may never have been a crime. Should not Britain, therefore, rejoice in its existing domestic protection of human rights? Of course there are those who seek to repeal the HRA and/or withdraw from the ECHR. In the introduction to this work the British Prime Minister, David Cameron, and the Home Secretary, Theresa May, were identified as being some of the chief 'culprits'. Indeed, only yesterday (at the time of writing) the Home Secretary did not miss the opportunity to have another 'dig' at the HRA, in issuing a statement on the eventual deportation of the suspected terrorist, Abu Qatada, from the UK to Jordan. (Previous attempts to deport Qatada had been prevented by the UK courts and the ECtHR because of real fears that either he would be tortured upon his return, or, at the very least, evidence used against him at any subsequent criminal trial would have been extracted through the torture of other suspects - see, for example: Othman (Abu Qatada) v. United Kingdom $\left.{ }^{109}\right)$.):

‘[Abu Qatada’s] departure marks the conclusion of efforts to remove him since 2001 and I believe this will be welcomed by the British public. I am glad that this government's determination to see him on a plane has been vindicated and that we have at last achieved what previous governments, Parliament and the British public have long called for. This dangerous man has now been removed from our shores to face the courts in his own country. I am also clear that we need to make sense of our human rights laws [my italics]...,110 
Theresa May was later quoted as saying that the option of Britain withdrawing from the ECHR should 'remain on the table'. ${ }^{111}$ Indeed, this view was supposedly shared by the Secretary of State for Justice, Chris Grayling, who has Ministerial responsibility for human rights issues. When also speaking about the deportation of Abu Qatata to Jordan, Grayling suggested that the Conservative party would advocate wholesale withdrawal from the ECHR. ${ }^{112}$ These are chilling reminders of the Conservative Party's apparent determination to repeal the UK's existing human rights protection after the next General Election, if it wins a majority of seats in the House of Commons.

The overall purpose of this article has been to present a defence of the HRA, but, because of restrictions on word limit, doing so has been restricted to one of the rights of the ECHR, Article 4, the freedom from slavery, servitude and forced labour. A particular feature of this human right, like others of a fundamental nature such as Article 2, the right to life, and Article 3, freedom from torture, is its positive or substantive nature, that is, its obligation imposed on states to prevent their violation, especially those by third parties. The conclusion here is that the HRA has been a success, at least in terms of Article 4 and the duty it has imposed on the UK to implement legislative measures preventing its abuse. Yes, there was maybe a hole in terms of statutory provision outlawing, say, the criminalisation of trafficking by British nationals abroad, and the trafficking of persons for reasons of non-sexual exploitation within the UK, but the government has now taken steps to address these in ss.109-110 of the Protection of Freedoms Act 2012. Of course governmental powers to appeal an unduly lenient sentence for all instances of human trafficking remain. And there is perhaps an argument for a modern Slavery Act consolidating the 
existing statutes dealing with this area, but whilst this would be administratively neater, as the government recognises, is this really a priority in practice?

What remains to be addressed, however, are other obligations imposed on a state by Article 4. This article has analysed the UK's duties to prevent violations of this right by reference to statutory measures. What about this country's non-statutory measures such as the better treatment of victims of human trafficking who are often prosecuted and/or deported? There is a high chance that people who have been returned to their country of origin will be retrafficked, the consequence of which: 'They have been doubly victimised: first by those who trafficked them and then by those who had the responsibility to protect them. ${ }^{113}$ There maybe comes a point, therefore, where more laws in this area are not the answer? Those investigating authorities on the ground, the British police, the UK Border Agency etc perhaps need to treat those that have been trafficked more as victims rather than as criminals - otherwise the UK will, arguably, continue to violate its substantive obligation to prevent abuses of Article 4, notwithstanding the fact that it has taken the step of implementing a robust criminal law response? An approach to this area should, therefore, involve more than the criminalisation of trafficking: it must be more human rights based. ${ }^{114}$ That is, most victims of trafficking are poor and uneducated economic migrants, so this area is possibly more of an issue of education and international development aid than criminality. ${ }^{115}$ And potential victims must sometimes 'go under the radar' to avoid strict laws on the employment of non-nationals, such as Britain's Immigration, Asylum and Nationality Act 2006 which imposes heavy penalties on employers who employ someone who is not from the EU, for example. In this respect, therefore, 
perhaps a degree of legalisation of the entry of unskilled work is required, as there is a demand for this type of labour across many countries in the EU? ${ }^{116}$

In 2006, whilst broadly accepting the UK's legislative measures in response to human trafficking, the JCHR did say that the current level of protection for victims as a whole was 'still far from adequate’. ${ }^{117}$ Indeed, the Anti-Trafficking Monitoring Group (ATMG), a coalition of individuals, organisations and agencies across the UK, which was set up in 2009 to monitor the UK's implementation of the Council of Europe's Convention on Action against Trafficking in Human Beings, published a damning report of the UK's treatment of victims four years after the 2006 JCHR report: Wrong Kind of Victim? One Year on: an Analysis of UK Measures to Protect Trafficked Persons. It argued that Britain had failed in its practical compliance of the Convention; ${ }^{118}$ significantly, the report castigated the National Referral Mechanism (NRM), the identification procedure established as part of the Convention to help identify the victims of trafficking, saying the system was 'not fit for purpose'. ${ }^{119}$ In June 2012, the UK's ATMG launched its second report into Britain’s compliance of the Council of Europe Convention: All Change: Preventing Trafficking in the UK. ${ }^{120}$ Echoing previous concerns expressed in this article, the report highlighted, for example, the undue emphasis that British anti-trafficking policy had placed on law enforcement and immigration control. ${ }^{121}$ Indeed, the UK's ATMG has only just launched its third report, In the Dock: Examining the UK's Criminal Justice Response to Trafficking. In it, the UK Government is warned that it risks 'losing the fight' against human trafficking unless, for example, the criminal justice system urgently improves its response to the crime. The ATMG found widespread evidence that many 
trafficked people were being prosecuted, while the criminal bosses who had enslaved them were going unpunished. ${ }^{122}$

Analysing Britain's non-statutory measures averting infringements of slavery, servitude and forced labour, including human trafficking, especially in the light of the UK's ATMG three reports into the UK's compliance with the Council of Europe's Convention on Action against Trafficking in Human Beings, will therefore be the focus of the next article in this study. Nonetheless, even before the completion of this next piece, it is perhaps inevitable from the conclusion here that much of this second article will concentrate on the UK's apparent reliance still to prosecute and (if a nonEU national) deport a victim of trafficking. This is despite the fact that, for example, Article 6 of the Palermo Protocol, which Britain ratified at least seven years ago, in 2006, obliges states to provide assistance to and protection of victims of trafficking, emphasising the point that a trafficked person is a victim rather than an accessory to the trafficking. And Article 7 encourages states to allow victims of trafficking to remain in their country of transit if they so wish.

\footnotetext{
* Senior Lecturer in Law, the University of Central Lancashire, Preston, UK. Email: idturner@uclan.ac.uk.

${ }^{1}$ This is stated in the main text because some academic commentators believe that a Constitution, which is not written, is not a proper constitution - see, for example: F. Ridley, 'There is no British Constitution: a Dangerous Case of the Emperor's Clothes' Parliamentary Affairs 44 (1988): 340.
} 
2 Amnesty TV, 'Theresa May and the Human Rights Act - Video’ The Guardian, 2 November 2011.

${ }^{3}$ [2010] UKSC 17.

4 Adam Wagner, ‘Go Compare’ 17 February 2011

http://ukhumanrightsblog.com/2011/02/17/go-compare/ (Accessed 25 October, 2012).

${ }^{5}$ Application no. 74025/01.

${ }^{6}$ Alison Little, 'PM: Giving Prisoners Vote Makes Me Feel Sick’ The Express, 24 November 2010.

${ }^{7}$ Patrick Wintour and Andrew Sparrow, 'I Won’t Give Prisoners the Vote, Says David Cameron’ The Guardian, 24 October 2012.

${ }^{8}$ Daniel Bentley, 'Home Secretary May "Wants Human Rights Act Scrapped”' The Independent, 2 October 2011.

${ }^{9}$ Nicholas Watt and Alan Travis, 'Tory Conference Cat-Fight: Clarke and May clash over Human Rights Act' The Guardian, 4 October 2011.

${ }^{10}$ Adam Wagner, 'Cat had Nothing to do with Failure to Deport Man’ 4 October 2011 http://ukhumanrightsblog.com/2011/10/04/cat-had-nothing-to-do-with-failure-todeport-man/ (Accessed 18 October, 2012).

11 Theresa May, 'It's my Job to Deport Foreigners who Commit Serious Crime - and I'll Fight any Judge who Stands in my way, says Home Secretary' The Mail, 13 February 2013.

12 To this end, the Home Secretary pledged to put these immigration rules into primary legislation forcing the courts to follow them, which is expected to form part of an Immigration Bill for the next Parliamentary session, 2013/14 - see: Alan Travis, 'Immigration Bill - the Devil's in the Detail' The Guardian, 8 May 2013.

${ }^{13}$ Ministry of Justice, 'Commission on a UK Bill of Rights Launched' 18 March 2011 http://www.justice.gov.uk/news/press-releases/moj/press-release-180311 (Accessed 18 October, 2012).

${ }^{14}$ Commission on a Bill of Rights, Do We Need a UK Bill of Rights? August 2011. http://www.justice.gov.uk/downloads/about/cbr/cbr-discussion-paper.pdf (Accessed 18 October, 2012).

${ }^{15}$ Commission on a Bill of Rights, A Second Consultation. July 2012. http://www.justice.gov.uk/downloads/about/cbr/second-consultation/cbr-secondconsultation.pdf (Accessed 18 October, 2012).

16 The Ministry of Justice, The Governance of Britain. July 2007 http://www.officialdocuments.gov.uk/document/cm71/7170/7170.pdf (Accessed 18 October, 2012).

${ }^{17}$ Parliamentary Joint Committee on Human Rights, A Bill of Rights for the UK? Twenty-Ninth Report of Session 2007-08 21 ${ }^{\text {st }}$ July 2008. http://www.publications.parliament.uk/pa/jt200708/jtselect/jtrights/165/165i.pdf (Accessed 18 October, 2012).

${ }^{18}$ http://www.justice.gov.uk/downloads/about/cbr/uk-bill-rights-vol-1.pdf and http://www.justice.gov.uk/downloads/about/cbr/uk-bill-rights-vol-2.pdf (Accessed 3 June, 2013).

${ }^{19}$ Ministry of Justice, 'The Commission on a Bill of Rights' Report- A UK Bill of Rights? - The Choice Before Us’18 December 2012. 
http://www.justice.gov.uk/news/press-releases/cbr/the-commission-on-a-bill-ofrights-report-a-uk-bill-of-rights-the-choice-before-us (Accessed 3 June, 2013). ${ }^{20}$ Andrew Grice, 'Tories' Bid for UK Bill of Rights declared 'Dead' After Review Ends in Stalemate' The Independent, 19 December 2012.

${ }^{21}$ XXXXXXX, 'Human Rights and Anti-Terrorism: A Positive Legal Duty to Infringe Freedom from Torture?' Studies in Conflict and Terrorism 35 (2012): 760; XXXXXX, 'Freedom from Torture in the 'War on Terror': is it Absolute?' Terrorism and Political Violence 23, no 3 (2011): 419; XXXXXX, 'Article 2 of the ECHR, the Investigative Obligation and the Shooting of Jean Charles de Menezes' Web Journal of Current Legal Issues no. 5 (2009); and XXXXXX, 'Suicide Terrorism, Article 2 of the ECHR and the Shooting of Jean Charles de Menezes' Web Journal of Current Legal Issues no 4 (2008).

${ }^{22}$ Emma Norton, 'Repeal the Human Rights Act? Slavery Arrests Another Reason to Think Again’ 12 September 2011 http://www.liberty-humanrights.org.uk/news/2011/repeal-the-human-rights-act-slavery-arrests-another-reas.php (Accessed 8 October, 2012).

${ }^{23}$ Op.cit.: 72.

${ }^{24}$ National Museums Liverpool, Resources for Schools: International Slavery Museum.

http://www.liverpoolmuseums.org.uk/learning/worksheets/ISM_teachers_pack.pdf (Accessed 4 October, 2012): 20.

${ }^{25}$ International Labour Organisation, Global Estimate of Forced Labour: Results and Methodology, 2012 http://www.ilo.org/wcmsp5/groups/public/---ed_norm/--declaration/documents/publication/wcms_182004.pdf (Accessed 4 July, 2012): 11.

${ }^{26}$ Ibid.: 13 .

${ }^{27}$ Ibid.

${ }^{28}$ Ibid.

${ }^{29}$ Alexandra Topping, 'Leighton Buzzard 'Slave’ Empire Uncovered in Major Police Raid’ The Guardian, 11 September 2011.

${ }^{30}$ Ibid.

31 Jerome Taylor, 'Men Rescued From Squalid Forced Labour Camp Refuse to Help Police’ The Independent, 13 September 2011.

32 Alison Campsie, 'Migrant Staff ‘Abused’ by Scots Firms’ The Herald, 15 May 2012.

${ }^{33}$ Pat Hurst, 'Deaf Girl Tells Court the Details of her Life 'Kept as a Slave in Cellar' The Independent, 28 February 2012. 
34 Jamie Doward, 'Trafficking in Britain: 'For Five months I Asked When I Would get a Job, but all I did was Clean Their Home’’ The Guardian, 6 November 2011.

${ }^{35}$ Ryszard Piotrowicz, 'States’ Obligations Under Human Rights Law Towards Victims of Trafficking in Human Beings: Positive Developments in Positive Obligations’ International Journal of Refugee Law 24, no. 2 (2012): 3.

${ }^{36}$ Application no. 73316/01

${ }^{37}$ Ibid.: para 122.

${ }^{38}$ Ibid:: para 129.

${ }^{39}$ Ibid.: para 123.

${ }^{40}$ (2000) 29 EHRR 245.

${ }^{41}$ Ibid.: para 115.

${ }^{42}$ Ibid.: para 116.

${ }^{43}$ Ibid.

${ }^{44}$ Ibid.

${ }^{45}$ Application no. 73316/01, at para 149.

${ }^{46}$ Ibid.: para 144.

${ }^{47}$ Ibid.: para 135.

${ }^{48}$ Ibid.: para 137.

${ }^{49}$ Ibid., at para 141.

${ }^{50}$ Holly Cullen, 'Siliadin v. France: Positive Obligations Under Article 4 of the European Convention on Human Rights’ Human Rights Law Review 11, no. 6 (2006): 592.

${ }^{51}$ Ibid.

52 Application no. 4239/08.

${ }^{53}$ Ibid.: paras 76-77.

${ }^{54}$ Ibid.: para 81.

55 See, for example: Edwards v. United Kingdom (Application no. 46477/99).

56 'Turning the Tables on Traffickers' Police Professional 20 September 2012, 22-23.

${ }^{57}$ Serious Organised Crime Agency, 'An Overview of Human Trafficking' http://www.soca.gov.uk/about-soca/about-the-ukhtc/an-overview-of-humantrafficking (Accessed 10 July, 2012).

${ }^{58}$ Ibid. Stoyanova - Vladislava Stoyanova, 'Dancing on the Borders of Article 4: Human Trafficking and the European Court of Human Rights in the Rantsev Case', Netherlands Quarterly of Human Rights 30, no.2 (2012): 171 - notes that the action element of the crime of human trafficking, that is, the recruitment, transportation, transfer, harbouring or receipt of a person, refers to the arrangement and facilitation of the alleged victim's migration; it does not refer to the actual abuses.

${ }^{59}$ Ibid. But the benefits to the trafficker in moving their victims across state frontiers are far greater; see, for example: Ryszard Piotrowicz, op.cit.: 4.

${ }^{60}$ Sandhya Drew, 'Human Trafficking: a Modern Form of Slavery?' European Human Rights Law Review no. 4 (2002): 489.

${ }^{61}$ Application no. 25965/04. 
${ }^{62}$ Ibid.: para. 281. So the ECtHR did not expressly state that trafficking was in fact slavery. But, the UK, for example, has an Anti-Slavery Day Act 2010. Section 1(1) states that a Government Minister shall specify a date which will be observed each year as Anti-Slavery Day in the UK. Interestingly, s.1(3) of the Act describes trafficking as slavery.

63 Ibid.: para. 280. For criticism of the ECtHR ruling in Rantsev, see, for example: Vladislava Stoyanova, op.cit.: 165-171. This article doubts, for example, whether the circumstances in Rantsev did in fact amount to a violation of Article 4 of the ECHR, later suggesting the ECtHR was exceeding the boundaries of Article 4 to accommodate trafficking generally.

${ }^{64}$ Directive 2011/36/EU of the European Parliament and of the Council of 5 April 2011 on preventing and combating trafficking in human beings and protecting its victims, and replacing Council Framework Decision 2002/629/JHA. http://eurlex.europa.eu/LexUriServ/LexUriServ.do?uri=OJ:L:2011:101:0001:0011:EN:PDF (Accessed 18 July, 2013).

${ }^{65}$ Application no. 25965/04.

${ }^{66}$ Ibid.: paras 282-289.

${ }^{67}$ Vladislava Stoyanova, op.cit.: 191.

${ }^{68}$ Ibid.: 192-193.

${ }^{69}$ Application no. 25965/04, at para 297.

${ }^{70}$ Ibid.: para 293.

${ }^{71}$ Case Comment, 'Rantsev v. Cyprus and Russia (App. No. 25965/04) Trafficking in Human Beings - Sexual Exploitation - 'Artiste' Visa Regime in Cyprus' European Human Rights Law Review (2010): 320.

${ }^{72}$ Ryszard Piotrowicz, op.cit.: 16-17.

73 Application no. 25965/04: para 308.

${ }^{74}$ Alison Topping, op.cit.

${ }^{75}$ Another reason for the criminalisation of compelling a person to perform forced or compulsory labour, as per s. 71 of the Coroners and Justice Act 2009, was the fact that the Gangmasters (Licensing) Act 2004 did not cover domestic workers who had been exploited - see, for example: Gwendolen Morgan, 'Is the UK a Safe Haven for Modern Slavery?’ New Law Journal 159, (2009): 1538.

${ }^{76}$ But this statute does not penalise those gangmasters who breach their licence terms, only those who operate without a licence - see, for example: Gwendolen Morgan, ibid.

${ }^{77}$ See, for example: Liberty, The Human Rights Act: What's Not to Love? http://www.liberty-human-rights.org.uk/human-rights/human-rights/the-humanrights-act/what-the-rights-mean/index.php (Accessed 10 July, 2013).

${ }^{78}$ Application no. 4239/08.

${ }^{79}$ Ibid.: para 80.

${ }^{80}$ Laura Harding, 'Four Members of Traveller Family Convicted in 'Slaves’ Trial', The Independent, 11 July 2012.

${ }^{81}$ Sentencing Remarks of HHJ Michael Kay QC, 12 July 2012 http://www.judiciary.gov.uk/Resources/JCO/Documents/Judgments/james-connorsjosie-sentencing-remarks-12072012.pdf (Accessed 5 July, 2013). 
82 BBC News, 'Connors Family Members Jailed for Servitude Offences' 7 May 2013 http://www.bbc.co.uk/news/uk-england-beds-bucks-herts-22433982 (Accessed 5 July, 2013).

${ }^{83}$ Virginia Mantouvalou, 'Modern Slavery: the UK Response’ Industrial Law Journal 39 (2009): 3-4.

${ }^{84}$ Equality and Human Rights Commission, Human Rights Review 2012: Article 4: Freedom from Slavery and Forced Labour http://www.equalityhumanrights.com/uploaded_files/humanrights/hrr_article_4.pdf (Accessed 12 June, 2013): 138-139.

${ }^{85}$ Ibid.: 145.

${ }^{86}$ Ibid.: 164.

${ }^{87}$ Ibid.: 163.

${ }^{88}$ Sally Lipscombe, Human Trafficking: UK Responses. House of Commons Library Note SN/HA/4324, 8 March 2013: 8. But these figures are surely the tip of the iceberg in terms of the actual estimates of victims of trafficking, in that there were thought to be 710 victims in the UK in 2010 and 946 in 2011? See, for example: 'Increase in Human Trafficking’ Police Professional, 25 October 2012: 11.

${ }^{89}$ Op.cit.: $138-139$.

${ }^{90}$ Liam Vernon, 'The Risks for the Labour Traffickers Are Still Too Low' The Independent, 12 July 2012.

${ }^{91}$ Sally Ramage, 'Human Trafficking in 2008 - Blowing Away Some Myths' Criminal Lawyer 184 (2008): 8.

${ }^{92}$ Northamptonshire Police, 'Thirteen Charged in Connection with 'Operation Ruby' 18 November 2009

http://www.northants.police.uk/default.aspx?id=3194\&datewant=yes (Accessed 10 July, 2013).

${ }^{93}$ Fraser Nelson, 'Connors Family Case Shows that Britain Must Fight Slave Trade' The Telegraph, 2 July 2012.

${ }^{94}$ Sally Lipscombe, op.cit.: p.8.

95 BBC News, 'Harrow Woman Convicted of Keeping Tanzanian as Slave' 16 March 2011 http://www.bbc.co.uk/news/uk-england-london-12710481 (Accessed 27 June, 2011)

${ }^{96}$ Centre for Social Justice, It Happens Here: Equipping the United Kingdom to Fight Modern Slavery. March 2013 http://www.centreforsocialjustice.org.uk/UserStorage/pdf/Pdf\%20reports/CSJ_Slaver y_Full_Report_WEB(5).pdf (Accessed 9 July, 2013): 5.

${ }_{97}$ Ibid.: 5.

${ }^{98}$ Ibid.

${ }^{99}$ Ibid. 
${ }^{100}$ Ibid.: 4.

${ }^{101}$ http://www.judiciary.gov.uk/Resources/JCO/Documents/Judgments/jamesconnors-josie-sentencing-remarks-12072012.pdf (Accessed 5 July, 2013).

${ }^{102}$ HM Government, Human Trafficking: the Government's Strategy. 2011

https://www.gov.uk/government/uploads/system/uploads/attachment_data/file/97845/ human-trafficking-strategy.pdf (Accessed 5 July, 2013): 23.

${ }^{103}$ HM Government, Report on the Internal Review of Human Trafficking Legislation May 2012 http://www.homeoffice.gov.uk/publications/crime/human-traffickinglegislation?view=Binary (Accessed 9 January, 2013): 4.

${ }^{104}$ Laurence Leigh, 'Trafficking People for Sexual Exploitation: the New Legislation' Criminal Law and Justice Weekly 176 (2012): 537. Leigh suggests, for example, the concepts of arrangement and facilitation are broad because there is no need that the accused person ever has to show that they have ever been in direct contact with the victim or proposed victim.

${ }^{105}$ HM Government, op.cit. (2012): 4.

${ }^{106}$ Ibid.: 11.

${ }^{107}$ Ibid.: 3.

108 Op.cit.: para 115.

${ }^{109}$ Application no. 8139/09.

${ }^{110}$ Home Office, 'Statement by Home Secretary Theresa May Following the Deportation of Abu Qatada on Sunday (7 ${ }^{\text {th }}$ July)' 7 July 2013

https://www.gov.uk/government/news/home-secretary-statement-on-abu-qatada

(Accessed 8 July, 2013).

${ }^{111}$ Christopher Hope, 'Theresa May: Abu Qatada case Shows Human Rights Act

'Must be Scrapped”' The Telegraph, 8 July 2013.

112 Christopher Hope and Tim Ross, 'Abu Qatada: Tories to Fight Next Election on Wholesale Human Rights Reform, says Chris Grayling’ The Telegraph, 7 July 2013.

113 Aiden McQuade, 'Slavery is Real - We Must Protect its Victims’ The Guardian, 2 February 2012.

114 Sandhya Drew, op.cit.: 490.

115 Sally Ramage, op.cit.: 10-11.

116 Sandhya Drew, op.cit.: 490.

117 Op.cit.: para 197.

${ }^{118}$ Anti-Trafficking Monitoring Group, Wrong Kind of Victim? One Year on: an Analysis of UK Measures to Protect Trafficked Persons. June 2010

http://www.antislavery.org/includes/documents/cm_docs/2010/a/1_atmg_report_for_ web.pdf (Accessed 6 July, 2013): 7.

${ }^{119}$ Ibid.: 9.

${ }^{120}$ Anti-Trafficking Monitoring Group, All Change: Preventing Trafficking in the UK. June 2012 http://s111999.gridserver.com/wp-content/uploads/2012/05/AntiTrafficking-Monitoring-Group-report-2012-All-Change-Prevention-low-res.pdf

(Accessed 8 July, 2013).

${ }^{121}$ Ibid.: 15.

122 Emily Duggan, 'UK is Warned it is Losing Fight Against Modern Slavery' The Independent, 11 June 2013. 